\title{
Anthracycline derivatives from a marine-derived New Zealand Streptomycete
}

\author{
Richard K. Phipps, ${ }^{a}$ John W. Blunt, ${ }^{a}$ Anthony L. J. Cole, ${ }^{b}$ and Murray H. G. Munro* ${ }^{a}$ \\ ${ }^{a}$ Department of Chemistry and ${ }^{b}$ School of Biological Sciences, \\ University of Canterbury, Private Bag 4800, Christchurch, New Zealand \\ E-mail:m.munro@chem.canterbury.ac.nz
}

Dedicated to Professor Rod Rickards on the occasion of his $70^{\text {th }}$ birthday

(received 18 May 04; accepted 30 Jun 04; published on the web 02 Jul 04)

\begin{abstract}
Four new anthracycline derivatives, $\left(7 S^{*} 9 R^{*} 10 R^{*}\right)$-pyrromycin $1,\left(7 R^{*} 9 R^{*} 10 R^{*}\right)$-pyrromycin 2 , 1-hydroxyauramycin $\mathrm{T}$ 3, 1-hydroxysulfurmycin $\mathrm{T} \mathbf{4}$, and the previously reported 1hydroxyaclacinomycin B 5 were isolated from a New Zealand marine-derived Streptomycete. All five compounds were cytotoxic against the P388 murine leukaemia cell line.
\end{abstract}

Keywords: Streptomycete, anthracyclines, pyrromycins, New Zealand, cytotoxic, P388

\section{Introduction}

Actinomycetes are well known as producers of biologically active compounds with members of the genus Streptomyces, in particular, being prolific producers of metabolites of a diverse range of biological activities. ${ }^{1}$ To date, a large number of anthracyclines have been isolated from a wide variety of Streptomycetes. ${ }^{1}$ Some of these anthracyclines, such as adriamycin and daunomycin, have found uses in medicine for the treatment of some cancers. ${ }^{2,3}$

\section{Results and Discussion}

In continuing studies on bioactive natural products from New Zealand micro-organisms one isolate, a Streptomyces sp. (CANU Fox 21-2-6), was of interest. The crude EtOAc extract from the fermentation showed strong cytotoxicity against the murine P388 leukaemia cell line. Furthermore, dereplication of this extract using an in-house approach (HPLC, MS and UV profiles) indicated good potential for novel chemistry. Further investigation led to the isolation of four new anthracycline derivatives, $\left(7 S^{*} 9 S^{*} 10 R^{*}\right)$-pyrromycin $1,\left(7 R^{*} 9 R^{*} 10 R^{*}\right)$-pyrromycin 
2, 1-hydroxyauramycin T 3, 1-hydroxysulfurmycin T 4, as well as the previously reported 1hydroxyaclacinomycin B 5.

The Streptomycete, (CANU Fox 21-2-6a), was isolated from well-weathered driftwood collected below the low-tide mark at the mouth of the Fox River on the West Coast of New Zealand. After 18 days fermentation in starch-casein broth under static conditions at $26^{\circ} \mathrm{C}$, the EtOAc extract prepared from the fermentation broth was fractionated using flash reverse-phase (RP) chromatography. Repeated chromatography on DIOL of selected fractions from the RP column yielded 5. Further purification of selected DIOL fractions by HPLC yielded 1, 2, 3 and 4.

The molecular formula of $\mathbf{1}$, a red solid, was deduced as $\mathrm{C}_{30} \mathrm{H}_{35} \mathrm{NO}_{11}$ (fourteen double bond equivalents) by HRESIMS and from ${ }^{13} \mathrm{C}$ NMR data. The ${ }^{1} \mathrm{H}$ NMR spectrum of $\mathbf{1}$ in $\mathrm{CDCl}_{3}$ showed three signals above $12 \mathrm{ppm}$, interpreted as hydrogen-bonded phenolic groups. The ${ }^{13} \mathrm{C}$ NMR experiment confirmed thirty carbon signals, five $\mathrm{CH}_{3}$, including one $\mathrm{OCH}_{3}$ and two $\mathrm{NCH}_{3}$, three $\mathrm{CH}_{2}$, nine $\mathrm{CH}$, and thirteen quaternary carbon signals.

The UV-visible spectrum of 1, maxima at 202, 234, 258, 290 and $492 \mathrm{~nm}$, was characteristic of a quinone. ${ }^{4}$ That spectral data, coupled with the ${ }^{1} \mathrm{H}$ and ${ }^{13} \mathrm{C}$ NMR chemical shifts, indicated the presence of an anthraquinone moiety containing three phenolic groups. In addition to the fourteen signals that could be assigned to the anthraquinone system, a single anomeric signal at $\delta_{\mathrm{C}} 101.9$ suggested that $\mathbf{1}$ was also a mono-glycoside.

The partial connectivities from COSY and HSQC NMR experiments established four subunits, a, b, c, and $\mathbf{d}$ as shown in Figure 1.

a

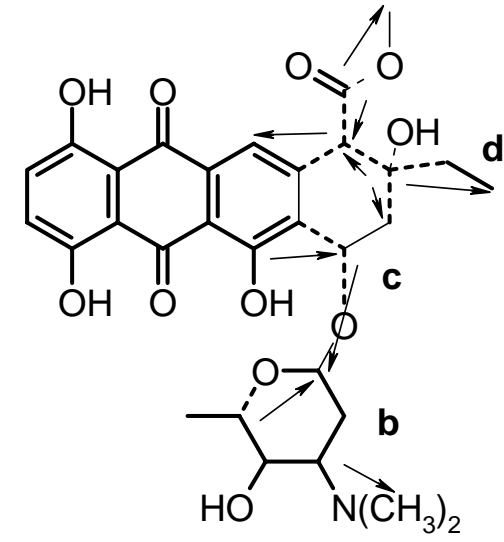

Figure 1. Substructures a-d and important CIGAR correlations for 1.

The assembly of these partial structures followed from a long range ${ }^{1} \mathrm{H}^{-13} \mathrm{C}$ correlation NMR (CIGAR) experiment. ${ }^{5}$ Correlations were observed from the $\mathrm{NCH}_{3}$ signals to a carbon in subunit b. The anomeric proton $\left(\delta_{\mathrm{H}} 5.56\right)$ showed strong correlations to two oxygenated $\mathrm{CH}$ 's $\left(\delta_{\mathrm{C}} 72.9\right.$ and 68.2) thus linking subunits $\mathbf{b}$ and $\mathbf{c}$ and closing the glycosidic ring. A correlation from $\mathrm{H} 7$ $\left(\delta_{\mathrm{H}} 5.10\right)$ to an oxygenated aromatic carbon $\left(\delta_{\mathrm{C}} 163.6\right)$ connected the subunits a and $\mathbf{c}$. The H11 aromatic proton $\left(\delta_{\mathrm{H}} 7.51\right)$ correlated to $\mathrm{C} 10\left(\delta_{\mathrm{C}} 58.5\right)$. $\mathrm{H} 8, \mathrm{H} 10$ and $\mathrm{H} 16\left(\delta_{\mathrm{H}} 2.28,2.56,4.07\right.$ and 
1.11) all correlated to an oxygenated quaternary carbon $\left(\delta_{C} 72.2\right)$ connecting subunit $\mathbf{d}$. The $\mathrm{OCH}_{3}$ group and $\mathrm{H} 10$ both correlated to a carbonyl $\left(\delta_{\mathrm{C}} 172.8\right)$ completing the assignment of the planar structure of $\mathbf{1}$ as a pyrromycin derivative. ${ }^{6}$

Examination of the coupling constants and a 2D NOE experiment enabled assignment of the relative stereochemistry of the anthraquinone moiety and the sugar residue in 1 . The starting point was the $\mathrm{H} 7$ proton $\left(\delta_{\mathrm{H}} 5.10\right)$ which showed a single ${ }^{3} J_{\mathrm{HH}}$ of $5 \mathrm{~Hz}$ to $\mathrm{H} 8 \mathrm{a}\left(\delta_{\mathrm{H}} 2.56\right)$ enabling placement of $\mathrm{H} 8 \mathrm{a}$ in a pseudo-axial position and $\mathrm{H} 8 \mathrm{~b}$ in a pseudo-equatorial position. NOE correlations were observed from $\mathrm{H} 15 \mathrm{a}\left(\delta_{\mathrm{H}} 1.56\right)$ to $\mathrm{H} 8 \mathrm{~b}\left(\delta_{\mathrm{H}} 2.28\right)$ and from $\mathrm{H} 15 \mathrm{~b}\left(\delta_{\mathrm{H}} 1.76\right)$ to $\mathrm{H} 10\left(\delta_{\mathrm{H}} 4.07\right)$ indicating that the ethyl side chain and the carboxyl groups were both pseudoaxial to give the relative stereochemistry of $\mathbf{1}$ as $\left(7 S^{*} 9 S^{*} 10 R^{*}\right)$-pyrromycin. The parent pyrromycin is the (7S9R10R)-stereoisomer. ${ }^{6}$ This stereoisomer also allows for the formation of the observed hydrogen-bond between the D-ring hydroxyl and carboxyl groups and completed the stereochemical assignment of the anthraquinone.

Based on the NOESY data the sugar could be identified as rhodosamine. Particularly important was the NOESY correlation seen from H5' $\left(\delta_{H} 4.26\right)$ to $H^{\prime}$ ' $\left(\delta_{H} 3.52\right)$ which placed these two protons in axial positions. If one or both of these protons had been in an equatorial position then NOESY correlations would not be observed. H3' also showed NOESY correlations to $\mathrm{H}^{\prime}{ }^{\prime}\left(\delta_{\mathrm{H}} 3.96\right)$ and $\mathrm{H} 2^{\prime}\left(\delta_{\mathrm{H}} 2.08\right)$ as expected for vicinal axial/equatorial orientations. The final stereocentre in the rhodosamine sugar residue was at the anomeric center. The anomeric proton $\left(\mathrm{H} 1\right.$ '; $\left.\delta_{\mathrm{H}} 5.55\right)$ showed no NOESY correlations to either axial proton at $\mathrm{H} 3$ ' and $\mathrm{H}^{\prime}$ ' and so could be assigned to an equatorial orientation in keeping with the only observed ${ }^{3} J_{\mathrm{HH}}$ coupling to the H2' protons of $2.5 \mathrm{~Hz}$. This asssigned stereochemistry confirmed the sugar residue as rhodosamine $\left(1^{\prime} R * 3\right.$ ' $S * 4$ ' $S * 5$ ' $\left.S *\right)$.

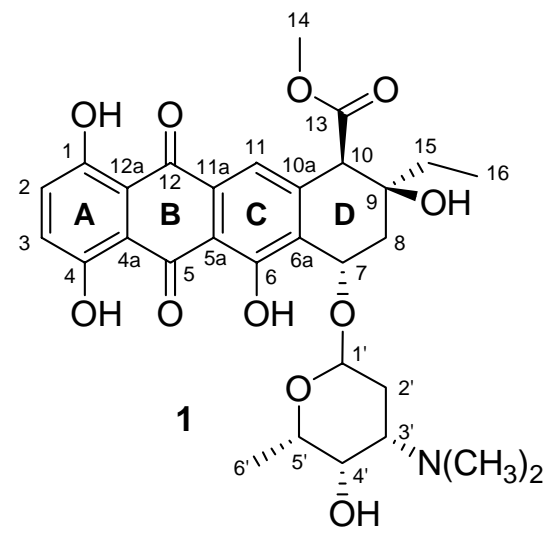

$\left(7 R^{*} 9 R^{*} 10 R^{*}\right)$-pyrromycin 2, also $\mathrm{C}_{30} \mathrm{H}_{35} \mathrm{NO}_{11}$ from HRESIMS, displayed almost identical spectral properties to $\mathbf{1}$, but the observed coupling patterns for $\mathrm{H} 7$ and $\mathrm{H} 8$ were more complex. $\mathrm{H} 7\left(\delta_{\mathrm{H}} 4.96\right)$ displayed as a triplet $\left({ }^{3} J_{\mathrm{HH}} 6.5 \mathrm{~Hz}\right)$ and the $\mathrm{H} 8$ protons $\left(\delta_{\mathrm{H}} 2.62,2.32\right)$ multiplets $\left({ }^{3} J_{\mathrm{HH}} 7.5,8 \mathrm{~Hz}\right.$ and $\left.{ }^{2} J_{\mathrm{HH}} 14 \mathrm{~Hz}\right)$. The $\mathrm{H} 15$ ethyl group signals $\left(\delta_{\mathrm{H}} 1.49\right)$ merged into a multiplet and both $\mathrm{H} 15$ and $\mathrm{H} 16\left(\delta_{\mathrm{H}} 0.98\right)$ had been shifted upfield. The variations observed in the ${ }^{1} \mathrm{H}$ 
NMR spectrum of 2 were attributed to a change in the stereochemistry of the D-ring. The change in the multiplicity seen for $\mathrm{H} 7$ indicated that the D-ring was in a different conformation allowing both couplings to the H8 protons to be observed. The slight increase in polarity and upfield shift of the ethyl protons suggested that the potential for a hydrogen-bond between the Dring hydroxyl and carboxyl groups was removed thereby placing both groups in pseudo-axial positions and limiting the possible stereoisomers to just two. Energy minimisation using the MM2 parameters in $\mathrm{Chem}^{\circledR} \mathrm{D}^{\circledR}$ (CambridgeSoft ${ }^{\circledR}$ ) showed dihedral angles (H7-C7-C8-H8a and $\mathrm{H} 7-\mathrm{C} 7-\mathrm{C} 8-\mathrm{H} 8 \mathrm{~b}$ ) of $55^{\circ}$ and $170^{\circ}$ and, $33^{\circ}$ and $145^{\circ}$ respectively for the possible stereoisomers. Application of the Karplus equation ${ }^{7}$ and comparison to experimental values $(8$ and $7.5 \mathrm{~Hz}$ ) limited the possibilities to just one stereoisomer, $\left(7 R^{*} 9 R^{*} 10 R^{*}\right)$-pyrromycin 2.

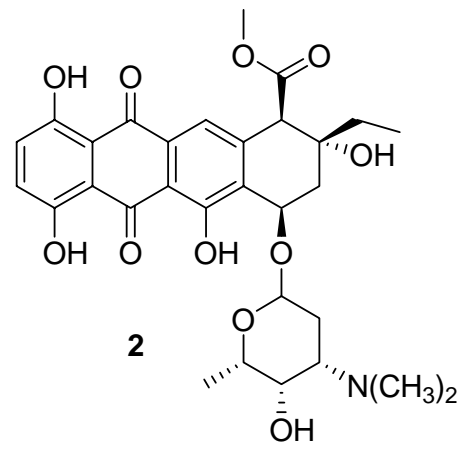

1-Hydroxyauramycin $\mathrm{T} 3, \mathrm{C}_{29} \mathrm{H}_{33} \mathrm{NO}_{11}$ from HRESIMS, also displayed very similar spectral properties to 1 . However, for 3, the signals arising from the ethyl group in the ${ }^{1} \mathrm{H}$ NMR spectrum of 1 were replaced with a singlet methyl resonating at $\delta_{\mathrm{H}} 1.43$. This, when coupled with the necessary decrease in mass and change in molecular formula allowed $\mathbf{3}$ to be assigned as the methyl derivative of 1 . The ${ }^{1} \mathrm{H}$ NMR signals for the $\mathrm{H} 7$ and $\mathrm{H} 8$ protons showed minor variation from those observed for $\mathbf{1}$ suggesting that the relative stereochemistry is identical to that established for $\mathbf{1}$.

a

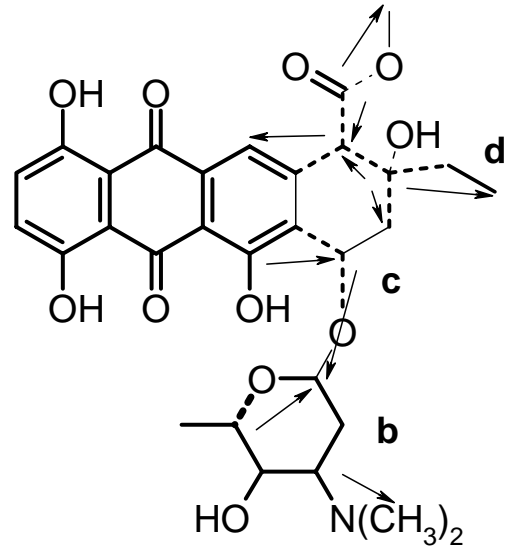

In the ${ }^{1} \mathrm{H}$ NMR spectrum of $4, \mathrm{C}_{31} \mathrm{H}_{35} \mathrm{NO}_{12}$ from HRESIMS, a methyl ketone $\left(\delta_{\mathrm{H}} 2.25\right)$ and a pair of isolated doublets $\left(\delta_{\mathrm{H}} 2.66,3.04\right)$ replaced the ethyl group signals seen in the ${ }^{1} \mathrm{H}$ NMR 
spectrum of 1. This methyl group showed a long range TOCSY correlation to the isolated doublets and a CIGAR correlation to a carbonyl group $\left(\delta_{\mathrm{C}} 210.6\right)$ to establish the structure and relative stereochemistry as 1-hydroxysulfurmycin T 4.

1-Hydroxyaclacinomycin B (5) was identified by comparison of NMR data to those in the literature. $^{8.9}$

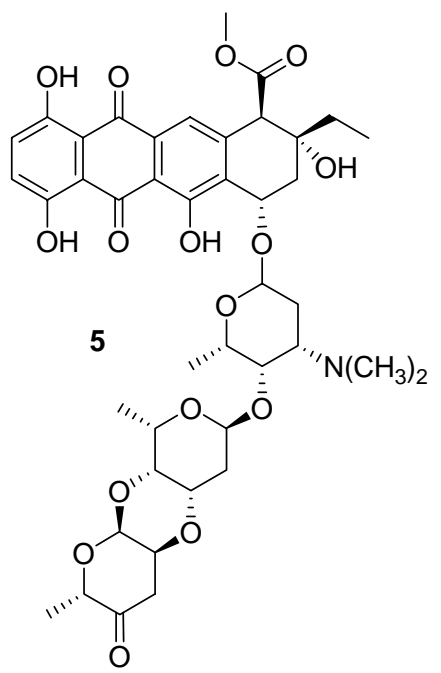

The anthracycline pyrromycin core is well established in a range of mono-, di- and triglycosides, but the auramycins and sulfurmycins have previously only been reported as triglycosides. ${ }^{9,10}$ This is the first report of mono-glycosylated auramycins and sulfurmycins.

The bioactivity evaluation showed that all four compounds displayed very good cytotoxicity against $\mathrm{P} 388$ cultured cells with $\mathrm{ID}_{50}$ values ranging from $0.4-0.06 \mu \mathrm{g} / \mathrm{mL}$.

\section{Experimental Section}

General Procedures. UV spectra were recorded with a Hewlett Packard 8452 diode array spectrometer. Optical rotation values were obtained on a Perkin Elmer 341 polarimeter. ${ }^{1} \mathrm{H},{ }^{13} \mathrm{C}$ APT and 2D NMR $\left({ }^{1} \mathrm{H}-{ }^{1} \mathrm{H}\right.$ COSY, ${ }^{1} \mathrm{H}-{ }^{13} \mathrm{C} \mathrm{HSQC},{ }^{1} \mathrm{H}-{ }^{13} \mathrm{C}$ CIGAR) spectra were recorded on a Varian INOVA $500 \mathrm{MHz}$ spectrometer. ESI mass spectra were acquired using a Micromass TOF LCT mass spectrometer. Column chromatography used $40 \mu \mathrm{M}$ Prep LC Bakerbond Octadecyl $\left(\mathrm{C}_{18}\right)$ and $40 \mu \mathrm{M}$ Prep LC Bakerbond Diol. Solvents for extraction and chromatography were distilled prior to use. HPLC was carried out using a Shimadzu LC-10ADvp equipped with an SPD-M10Avp photodiode array detector.

Isolation of the microbial strain. The outer layer of driftwood material collected at the mouth of the Fox River on the West Coast of New Zealand was scraped clean to remove superficial organisms. The driftwood was then thinly sliced and sections placed on agar plates containing isolation medium (15 g/L agar and fresh seawater $(1 \mathrm{~L}))$ plus the antibiotics chloramphenicol, 
ampicillin $(100 \mu \mathrm{g} / \mathrm{L})$ and streptomycin sulphate $(50 \mu \mathrm{g} / \mathrm{L}))$. Microbial colonies growing out of the wood sections were transferred to a medium for sporulation (Gibco PDA $39 \mathrm{~g} / \mathrm{L}$ and fresh seawater $(1 \mathrm{~L}))$ containing the antibiotics chloramphenicol, ampicillin, $(100 \mu \mathrm{g} / \mathrm{L})$ and streptomycin sulphate $(50 \mu \mathrm{g} / \mathrm{L}))$.

Fermentation and isolation. Streptomyces sp. (CANU Fox 21-2-6a) was fermented in starchcasein broth (glycerol $10 \mathrm{~g} / \mathrm{L}$, peptone $1400.3 \mathrm{~g} / \mathrm{L}, \mathrm{KNO}_{3} 2 \mathrm{~g} / \mathrm{L}, \mathrm{NaCl} 2 \mathrm{~g} / \mathrm{L}, \mathrm{K}_{2} \mathrm{HPO}_{4} 2 \mathrm{~g} / \mathrm{L}$, $\mathrm{MgSO}_{4} .7 \mathrm{H}_{2} \mathrm{O} 50 \mathrm{mg} / \mathrm{L}, \mathrm{CaCO}_{3} 20 \mathrm{mg} / \mathrm{L}, \mathrm{FeSO}_{4} .7 \mathrm{H}_{2} \mathrm{O} 10 \mathrm{mg} / \mathrm{L}$, distilled water $1 \mathrm{~L}, \mathrm{pH}$ 7.0) under static conditions at $26^{\circ} \mathrm{C}$ for 18 days. The culture broth $(10 \mathrm{~L})$ was homogenised and filtered through celite. The cellular material was extracted by stirring with ethyl acetate overnight $(3 \times 200 \mathrm{~mL})$ as was the culture filtrate $(3 \times 2 \mathrm{~L})$. The combined ethyl acetate extracts were concentrated under vacuum yielding a deep red viscous oil $(7 \mathrm{~mL})$. The residue was fractionated on $\mathrm{C}_{18}$ using a steep, stepped solvent gradient $\left(\mathrm{MeOH} / \mathrm{H}_{2} \mathrm{O}(10 \%)\right.$ to $\mathrm{MeOH}$ to DCM). The fractions that eluted between $\mathrm{MeOH}$ and DCM were combined and repeatedly chromatographed on DIOL with gradient elution by petroleum ether/DCM to EtOAc/DCM to $\mathrm{MeOH} /$ EtOAc. Fractions were purified by analytical HPLC on $\mathrm{C}_{18}$ and eluted with $\left(\mathrm{MeCN} / \mathrm{H}_{2} \mathrm{O}\right.$ $(32 \%)(0.05 \% \mathrm{TFA})$ ) to yield $\left(7 S^{*} 9 S^{*} 10 R^{*}\right)$-pyrromycin (1) $(2.0 \mathrm{mg})$, (7R*9R*10R*)pyrromycin (2) (1.4 mg), 1-hydroxyauramycin T (3) (1.4 mg), 1-hydroxysulfurmycin T (4) (1.4 $\mathrm{mg})$.

(7S*9R*10R*)-Pyrromycin (1). Deep red solid; $[\alpha]^{20}{ }_{\mathrm{D}}=+128.0^{\circ}(0.25 \mathrm{mg} / \mathrm{mL}, \mathrm{MeOH})$; UV $(\mathrm{MeOH}) \lambda_{\max } 202,234,258,290,492 ;{ }^{1} \mathrm{H}$ NMR $\left(\mathrm{CD}_{3} \mathrm{OD}, 500 \mathrm{MHz}\right) \delta 7.51(\mathrm{~s}, 1 \mathrm{H}, \mathrm{H} 11), 7.08$ (s, 2H, H2 H3), 5.56 (d, J=2.5 Hz, 1H, H1'), 5.10 (d, J=5 Hz, 1H, H7), 4.26 (q, $J=6.5,13 \mathrm{~Hz}$, 1H, H5'), 4.07 (s, 1H, H10), 3.96 (s, 1H, H4'), 3.75 (s, 3H, 14OMe), 3.52 (m, 1H, H3'), 2.87 (s, 6H, 7'N(Me) $)_{2}$ ), 2.56 (dd, $\left.J=5,15 \mathrm{~Hz}, 1 \mathrm{H}, \mathrm{H} 8 \mathrm{ax}\right), 2.28$ (d, J=15 Hz, 2H, H8eq H2'ax), 2.08 (dt,


6'Me), $1.11(\mathrm{t}, J=7 \mathrm{~Hz}, 3 \mathrm{H}, 16 \mathrm{Me}) ;{ }^{13} \mathrm{C} \mathrm{NMR}\left(\mathrm{CD}_{3} \mathrm{OD} 125 \mathrm{Mhz}\right) \delta 191.6$ (C5), 186.7 (C12), 172.8 (C13), 163.6 (C6), 159.4 (C1), 159.0 (C4), 144.1 (C10a), 133.8 (C11a), 133.1 (C6a), 131.5 (C3), 131.1 (C2), 121.2 (C11), 116.0 (C5a), 113.4 (C12a, C4a), 101.9 (C1'), 72.9 (C7), 72.2 (C9), 68.2 (C5'), 66.1 (C4'), 63.9 (C3'), 58.5 (C10), 53.5 (C14 OMe), 40.7 (NMe), 36.2 (C8), 33.6 (C15), 28.1 (C2'), 17.2 (C6'), 7.5 (C16); HRESIMS m/z 585.2218 (calcd for $\mathrm{C}_{30} \mathrm{H}_{35} \mathrm{NO}_{11}$ $585.2210)$.

(7R*9R*10R*)-Pyrromycin (2). Deep red solid; $[\alpha]^{20}{ }_{\mathrm{D}}=+224.0^{\circ}(0.125 \mathrm{mg} / \mathrm{mL}, \mathrm{MeOH})$; UV $(\mathrm{MeOH}) \lambda_{\max } 202,234,258,290,492 ;{ }^{1} \mathrm{H}$ NMR $\left(\mathrm{CD}_{3} \mathrm{OD}, 500 \mathrm{MHz}\right) \delta 7.60$ (s, 1H, H11), 7.38 (s, 2H, H2 H3), 5.58 (br s, 1H, H1'), 4.96 (t, $J=2.5 \mathrm{~Hz}, 1 \mathrm{H}, \mathrm{H} 7), 4.17$ (q, J=7, $12.5 \mathrm{~Hz}, 1 \mathrm{H}$, H5'), 3.99 (s, 1H, H10), 3.95 (br s, 1H, H4'), 3.78 (s, 3H, 14OMe), 3.52 (br d, J = $11 \mathrm{~Hz}, 1 \mathrm{H}$, H3'), 2.91 (s, 3H, 7'NMe), 2.85 (s, 3H, 7'NMe), 2.62 (dd, J=7.5, 14 Hz, 1H, H8ax), 2.32 (dd, $J=$ 8, $14 \mathrm{~Hz}, 1 \mathrm{H}, \mathrm{H} 8 \mathrm{eq}$ ), 2.29 (dd, $J=8,14 \mathrm{~Hz}, 1 \mathrm{H}, \mathrm{H} 2$ 'ax), 2.06 (br s, 1H, H2'eq), 1.49 (m, 2H, H15), 1.33 (d, $J=6 \mathrm{~Hz}, 3 \mathrm{H}, 6$ 'Me), 0.98 (t, $J=7 \mathrm{~Hz}, 3 \mathrm{H}, 16 \mathrm{Me}$ ); HRESIMS m/z 585.2211 (calcd for $\mathrm{C}_{30} \mathrm{H}_{35} \mathrm{NO}_{11} 585.2210$ ). 
1-Hydroxyauramycin T (3). Deep red solid; UV (MeOH) $\lambda_{\max } 202,234,258,290,492 ;{ }^{1} \mathrm{H}$ NMR (CD $\left.{ }_{3} \mathrm{OD}, 500 \mathrm{MHz}\right) \delta 7.67$ (s, 1H, H11), 7.37 (s, 2H, H2 H3), 5.56 (br s, 1H, H1'), 5.13 (d, $J=5 \mathrm{~Hz}, 1 \mathrm{H}, \mathrm{H} 7), 4.24$ (q, $J=7.5,14 \mathrm{~Hz}, 1 \mathrm{H}, \mathrm{H} 5$ '), 4.09 (s, 1H, H10), 3.91 (br s, 1H, H4'), 3.71 (s, 3H, 14OMe), 3.46 (br d, $J=11.5 \mathrm{~Hz}, 1 \mathrm{H}, \mathrm{H} 3$ '), 2.88 (br s, 3H, 7'NMe), 2.78 (br s, 3H, $7^{\prime} \mathrm{NMe}$ ), 2.58 (dd, $\left.J=6,15 \mathrm{~Hz}, 1 \mathrm{H}, \mathrm{H} 8 \mathrm{ax}\right), 2.20$ (d, J = $\left.15 \mathrm{~Hz}, 1 \mathrm{H}, \mathrm{H} 8 \mathrm{eq}\right), 2.15$ (m, 1H, H2'ax), 2.02 (dt, $J=3.5,12.5 \mathrm{~Hz}, 1 \mathrm{H}, \mathrm{H} 2$ 'eq), 1.38 (s, 3H, 16Me), 1.31 (d, $J=6.5 \mathrm{~Hz}, 3 \mathrm{H}, 6{ }^{\prime} \mathrm{Me}$ ); HRESIMS m/z 571.2059 (calcd for $\mathrm{C}_{29} \mathrm{H}_{33} \mathrm{NO}_{11}$ 571.2054).

1-Hydroxysulfurmycin T (4). Deep red solid; UV (MeOH) $\lambda_{\max } 202,234,258,290,492 ;{ }^{1} \mathrm{H}$ NMR (CD $\mathrm{OD}, 500 \mathrm{MHz}) \delta 7.71(\mathrm{~s}, 1 \mathrm{H}, \mathrm{H} 11), 7.36$ (s, 2H, H2 H3), 5.49 (br s, 1H, H1'), 5.10 (br s, 1H, H7), 4.26 (q, J = 7, 13 Hz, 1H, H5'), 4.24 (s, 1H, H10), 3.93 (br s, 1H, H4'), 3.71 (s, $3 \mathrm{H}, 14 \mathrm{OMe}$ ), 3.46 (br d, $J=11.5,1 \mathrm{H}, \mathrm{H} 3$ ), 3.04 (d, $J=16.5 \mathrm{~Hz}, 1 \mathrm{H}, \mathrm{H} 15 \alpha$ ), 2.88 (br s, 3H, 7'NMe), 2.77 (br s, 3H, 7'NMe), 2.66 (d, J = 16.5 Hz, 1H, H15ß), 2.53 (br s, 2H, H8), 2.25 (s, $3 \mathrm{H}, 17 \mathrm{Me}$ ), 2.15 (m, 1H, H2'ax), 2.03 (m, 1H, H2'eq), 1.32 (d, $\left.J=6.5 \mathrm{~Hz}, 3 \mathrm{H}, 6{ }^{\prime} \mathrm{Me}\right)$; HRESIMS $\mathrm{m} / \mathrm{z} 613.2158$ (calcd for $\mathrm{C}_{31} \mathrm{H}_{35} \mathrm{NO}_{12} 613.2159$ ).

\section{Acknowledgements}

We thank Mr B. Clark for mass spectrometric analysis, Ms G. Ellis for bioactivity assays, and $\mathrm{Mr}$ M. Walters for assistance with collection trips.

\section{References}

1. Behal, V. Adv. App. Microbiology 2000, 47, 113.

2. Yagi, A.; Okamura, N.; Haraguchi, H.; Abo, T.; Hashimoto, K. Phytochem. 1993, 33, 87.

3. Kren, V.; Martínková, L. Curr. Med. Chem. 2001, 8, 1313.

4. Doyle, T. W.; Nettleton, D. E.; Grulich, R. E.; Balitz, D. M.; Johnson, D. L.; Vulcano, A. L. J. Am. Chem. Soc. 1979, 101, 7041.

5. Hadden, C. E.; Martin, G. E.; Krishnamurthy, V. V. Mag. Reson. Chem. 2000, 38, 143-147.

6. Brockmann, H.; Lenk, W. Chem. Ber. 1959, 92, 1904.

7. Haasnoot, C. A. G.; DeLeeuw, F. A. A. M.; Altona, C. A. Tetrahedron 1980, 36, 2783.

8. Parkinson, J. A.; Sadler, I. H.; Pickup, M. B.; Tabor, A. B. Tetrahedron 1995, 51, 7215.

9. Nakata, M.; Saito, M.; Inouye, Y.; Nakamura, S.; Hayakawa, Y.; Seto, H. J. Antibiotics 1992, 45, 1599.

10. Fujiwara, A.; Tazoe, M.; Hoshino, T.; Sekine, Y.; Masuda, S.; Nomura, S. J. Antibiotics 1981, 34, 912. 